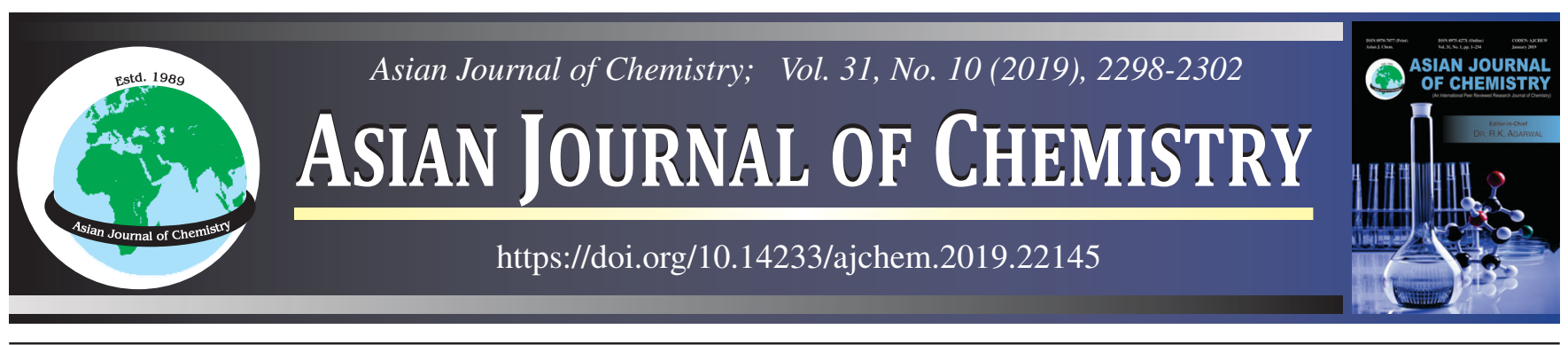

\title{
Kinetic Modeling of Hydrodistillation of Essential Oil Production from Orange (Citrus sinensis) Peels on Pilot Scale
}

\author{
Dinh Nhat Do ${ }^{1, *}$, Ngoc Tu Pham ${ }^{1}$, Tri Duc Lam ${ }^{2}$, Long Giang Bach ${ }^{2,3, *}$, \\ Duy Chinh NGuYen ${ }^{2}$, Quoc Toan Tran ${ }^{4}$ and Le Thi Hong Nhan ${ }^{5}$
}

${ }^{1}$ Faculty of Chemical Engineering and Food Technology, Nguyen Tat Thanh University, Ho Chi Minh City, Vietnam ${ }^{2}$ NTT Hi-Tech Institute, Nguyen Tat Thanh University, Ho Chi Minh City, Vietnam ${ }^{3}$ Center of Excellence for Biochemistry and Natural Products, Nguyen Tat Thanh University, Ho Chi Minh City, Vietnam ${ }^{4}$ Institute of Natural Products Chemistry, Vietnam Academy of Science and Technology, Hanoi, Vietnam ${ }^{5}$ Department of Chemical Engineering, HCMC University of Technology, VNU-HCM, Ho Chi Minh City, Vietnam

*Corresponding authors: E-mail: ddnhat@ntt.edu.vn, blgiang@ntt.edu.vn

Present study involves to the pilot scale hydrodistillation process for production of essential oil of orange peels. The production of orange peels essential oil and the effect of several factors such as time, temperature and the ratio of solid/solvent on yield and quality were studied. In this work, we used fresh orange peels of $C$. sinensis (orange). The quantitative and qualitative analyses of the essential oils of orange peels were performed by GC/MS and sensory analysis. The maximum yield of orange peels essential oil was $1.2384 \%$ (fresh matter) at distillation conditions (ground fresh material, the material-water ratio of 1:2, time of 105 min from the first drop, the temperature of 132 $\left.{ }^{\circ} \mathrm{C}\right)$. Kinetic studies of hydrodistillation process showed that the extraction of orange peels essential oil follows first order kinetic $\left(\mathrm{R}^{2}>0.95\right)$. Limonene is the dominant component of the orange peels essential oil that was identified by chromatography-mass spectrometry ( $94.22 \%$ ) The results of test indicated the orange peels essential oil has good qualities which were suitable to the National Standards of Vietnam.

Keywords: Kinetic Modeling, Hydrodistillation, Orange peels essential oil, Pilot scale, GC/MS.

\section{INTRODUCTION}

In recent years, human have tended to use many products derived from nature [1-3]. Among all products, essential oils with many wonderful uses have been used in many fields and purposes such as manufacture of antimicrobial compounds, medicine and food additives. Essential oils are odorous oily liquids of complex mixtures extracted from several plant organs such as flowers, seeds, etc. [4-6]. Orange belongs to the citrus genus, which is popular in Southeast Asian countries including Vietnam. In citrus fruits, the peel contains many volatile compounds including essential oils [7]. Citrus essential oils play an important role in the antioxidant antiviral, anticancer, antiinflammatory, antiallergenic and analgesic activities [8]. As a result, citrus essential oils are considered as an important quality indicator for utilization of citrus in medicine, food, cosmetics [8]. According to previous studies, pomelo oil was used in foods as a potential preservative [9-11]. The previous study determined that the essential oil of grapefruit peel had a broad spectrum of antimicrobial activities against Escherichia coli, Enterococcus faecalis, Staphylococcus epidermidis and Salmonella typhimurium $[12,13]$. Citrus essential oils are helpful for the treatment of headaches, gingivitis, sinusitis, insomnia, immune system support, colds and flu, burns, insect bites and various skin diseases [14]. Moreover, researchers concluded that anticancer activities and digestion-promoting capabilities are due to the presence of limonene in sour orange essential oil [15]. Another advantage of essential oils is the unnecessity of chemical preservatives in cosmetic preparations that contain oils including creams, gels, and ointments [16].

The hydrodistillation method became increasingly popular for extraction of essential oils from plant materials due to the simplicity of installations and ease of conduction. Another study utilized steam distillation method for extraction of essential

This is an open access journal, and articles are distributed under the terms of the Attribution 4.0 International (CC BY 4.0) License. This license lets others distribute, remix, tweak, and build upon your work, even commercially, as long as they credit the author for the original creation. You must give appropriate credit, provide a link to the license, and indicate if changes were made. 
oils from lavender and artemisia leaves [17]. In addition, hydrodistillation and steam distillation were selected for extraction of Teucrium essential oil [18]. In another study, the yield of the citronella essential oil extracted by steam distillation was also optimized [19]. Another conventional extraction method is hydrodistillation which requires the material to be distilled at a temperature below $100{ }^{\circ} \mathrm{C}$. In addition, a previous study demonstrated that, when compared with traditional hydrodistillation method, microwave-assisted hydrodistillation was superior in terms of energy consumption and time when extracting essential oils from Thymus vulgaris L [20-22].

There have been many studies of oil extraction by hydrodistillation methods to solve the problem of separation efficiency, composition and utility of essential oils [23-26]. However, studies on kinetics of essential oils hydrodistillation were lacking. The kinetic studies could contribute not only to the fundamental knowledge, but also to improvement in optimization, operation, and industrial distillation processes. Kinetic models play an important function for hydrodistillation processes under both technological and economic perspectives. Another study demonstrated the relationship between drying of the material to the performance and composition of essential oil [27-31].

Previous studies have showed that the traditional extraction methods are easy to implement. However, the majority of the researches which optimized parameters in the extraction processing are limited to the laboratory scale. Therefore, the application of these studies to industrial productions could be difficult. Differences in scale of production will significantly affect the yield and quality of essential oils. Therefore, the purpose of this study is to optimize the factors that affect the yield of the distillation process and evaluate the quality of the extracted essential oil. The results of this study provide the optimum technological parameters to produce the maximized essential oils. The results of this study on the pilot scale could be useful for technology transfer, which might become the solution to shorten the gap between research and production.

\section{EXPERIMENTAL}

Fresh fruit orange (C. sinensis) was provided from My Hoa District, Vinh Long province, Vietnam. They were peeled and the peels were washed with water and stored at standard temperature. Materials were used within 5 days in this study and were determined for moisture.

Processing description: Different orange peel samples were cut or ground into pieces of approximately $0.2-0.5 \mathrm{~cm}$, then they were fed into hydrodistillation machine. The process was carried out at different temperature points $\left(120,126,132,136{ }^{\circ} \mathrm{C}\right)$ and ratio of material-water $(1: 1,1: 2,1: 3,1: 4)$ using a distillation tower equipment $(10 \mathrm{~kg} / \mathrm{batch})$. After distillation processing, hydrosol and essential oil mixture were obtained. Raw essential oil was dehydrated using anhydrous sodium sulfate to remove residual water, then filtered by Whatman No. 1 filter paper and stored in brown glass jar until being analyzed and used.

Sensory properties: A $10 \mathrm{~mL}$ of the sample was dropped into a $20 \mathrm{~mL}$ glass. To observe the sample, the environment should have sufficient light, avoids direct light and has no other nearby colour source and no strange smell. Test samples were prepared according to TCVN 11424:2016.
Physical properties: The physical properties of orange essential oil are defined including refractive index, specific gravity and optical rotation according to TCVN 11424:2016. Density of the essential oils was determined by pouring essential oils into the beaker and then weighting them. The density of the essential oils were calculated as follows:

Specific gravity $(\%)=\frac{\text { Weight of essential oil sample }}{\text { Volume of essential oil in the beaker }} \times 100(1)$

Determination of specific gravity of essential oils: First, a clean dry bottle was weighed. Second, distilled water was poured into the bottle and estimated, then the same volume of oil was put into the same bottle and weighed. The specific gravity was calculated as follows:

Density $(\%)=\frac{\text { Weight of particular volume of oil extracted }}{\text { Weight of equal volume of water }} \times 100(2)$

Chemical analysis of essential oils by gas chromatography-mass spectrometry (GC-MS) analysis: A gas chromatography-mass spectrometry (GC-MS) is used to analyze the composition of the essential oils of all extraction methods. Equipment including GC Agilent 6890N, MS 5973 inert, HP5MS column, head column pressure $9.3 \mathrm{psi}$. A sample of essential oil $(25 \mu \mathrm{L})$ in $1.0 \mathrm{~mL} n$-Hexane. GC-MS are taken under the following conditions: carrier gas $\mathrm{He} ; 1.0 \mathrm{~mL} / \mathrm{min}$ flow rate; 1:100 split; injection volume $1.0 \mu \mathrm{L}$; injection temperature $250^{\circ} \mathrm{C}$; oven temperature progress included an initial hold at $50{ }^{\circ} \mathrm{C}$ for $2 \mathrm{~min}$, a rise to $80^{\circ} \mathrm{C}$ at $2{ }^{\circ} \mathrm{C} / \mathrm{min}$, a rise to $150{ }^{\circ} \mathrm{C}$ at $5^{\circ} \mathrm{C} / \mathrm{min}$, a rise to $200^{\circ} \mathrm{C}$ at $10^{\circ} \mathrm{C} / \mathrm{min}$ and rise to $300^{\circ} \mathrm{C}$ at 20 ${ }^{\circ} \mathrm{C} / \mathrm{min}$ for $5 \mathrm{~min}$.

Kinetic modeling of essential oils distillation: Modeling of the extraction process is applied for the evaluation of variable conditions affecting the extraction. It is also recognized as a vital step for devising an efficient method.

First-order kinetic was given by the equation [26]:

$$
\begin{aligned}
& -\frac{\mathrm{d}_{\mathrm{m}}}{\mathrm{dt}}=\mathrm{km} \\
& \ln \frac{\mathrm{m}_{\mathrm{o}}}{\mathrm{m}}=\mathrm{kt} \\
& \ln \frac{1}{1-\mathrm{u}}=\mathrm{kt}
\end{aligned}
$$

where, $\mathrm{m}=$ average concentration of essential oil in the material at any time $t ; \mathrm{m}_{\mathrm{o}}=$ initial concentration of essential oil before distillation starts; $\mathrm{t}=$ time of distillation; $\mathrm{u}=$ fraction of essential oils extracted.

Calculation of essential oil yield: The yield of essential oil extracted in each experiment was calculated based on fresh material (eqn. 7).

$$
\text { Yield }(\%)=\frac{\text { Weight of esssential oil extracted }}{\text { Weight of fresh material }(10 \mathrm{~kg})} \times 00
$$

\section{RESULTS AND DISCUSSION}

Effect of distillation time on yield: Distillation time depends on several factors such as raw materials, the solvent to solid ratio, temperature, size of samples. The longer distillation time, the longer distillation time was, resulting in higher amount of 
gained essential oil. However, by extending the distillation to a certain period, it is observed that the amount of essential oil ceased to rise, adversely affecting the quality of the product. This is due to the exposure to the temperature of some substances, leading to denatured and higher energy consumption. Therefore, it is necessary to determine the suitable distillation time. The distillation time was measured starting from the first drop to constant change in recovered essential oil. Other conditions include the temperature of $132{ }^{\circ} \mathrm{C}$, ratio of $1: 2$ with ground sample. Samples which were used in the experiments were fresh samples (moisture content was $78.35 \%$ ) that were not stored (Table-1). Fig. 1 showed the correlation between the time of distillation and the percentage change in mass of orange essential oil obtained in different experiments.

\begin{tabular}{cccc}
\multicolumn{4}{c}{ TABLE-1 } \\
& MOISTURE CONTENT OF MATERIAL \\
& AT DIFFERENT STORAGE DAYS \\
\hline Material & Storage (day) & Moisture (\%) & Dry weight $(\mathrm{kg})$ \\
\hline \multirow{3}{*}{ Orange peel } & Fresh & 78.35 & 2.17 \\
& 1 & 76.69 & 2.14 \\
& 3 & 58.03 & 2.73 \\
& 5 & 8.93 & 5.28 \\
\hline
\end{tabular}

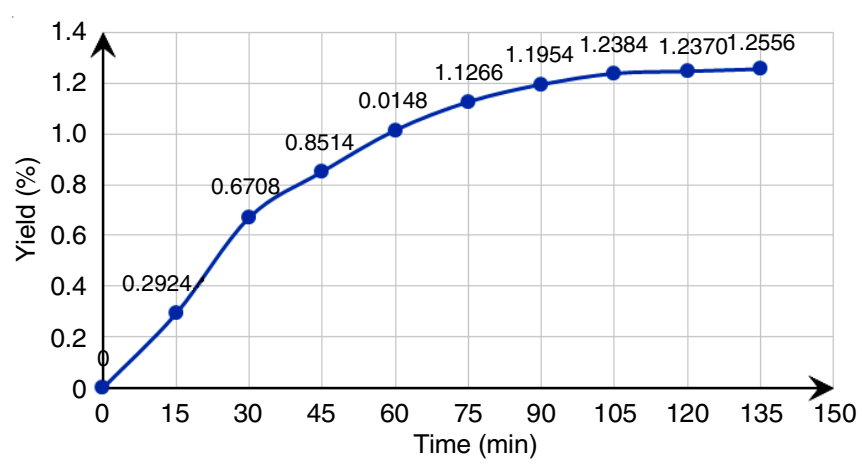

Fig. 1. Effect of distillation time on orange peels essential oil yield

Based on the effect of distillation time on the yield of orange peels essential oil (Fig. 1), it found that the highest yield at $1.2556 \%$, was achieved at $135 \mathrm{~min}$ starting from the first drop. However, the optimal optimum condition was chosen at 105 min corresponding to the oil yield of $1.2384 \%$. It is because after $105 \mathrm{~min}$, the oil content only increased by $0.0172 \%$, which is marginal considering the additional time of distillation of 45 min. Because essential oil content remained in orange peel were not much and most of the components have higher boiling points, part of essential oil was dissolved in condensed water. Therefore, the yield would not increase significantly.

Effect of temperature on yield: One of the important factors affected on the distillation process of essential oil of orange peels was temperature. High temperatures promote the diffusion rate, the convection of solvent and the reduction of fuel viscosity, thus increasing the distillation efficiency. But at high temperature, some substances in the essential oil decomposed, affecting the extraction efficiency and the quality of essential oils. After the time of initial distillation was fixed (105 min), other distillation processes had been carried out at different temperatures and ratio, ground sample. Samples which used in the experiments were fresh samples that were not stored. The correlation between the distillation temperature and yield of the orange peel essential oil extracted after distillation has shown in Fig. 2.

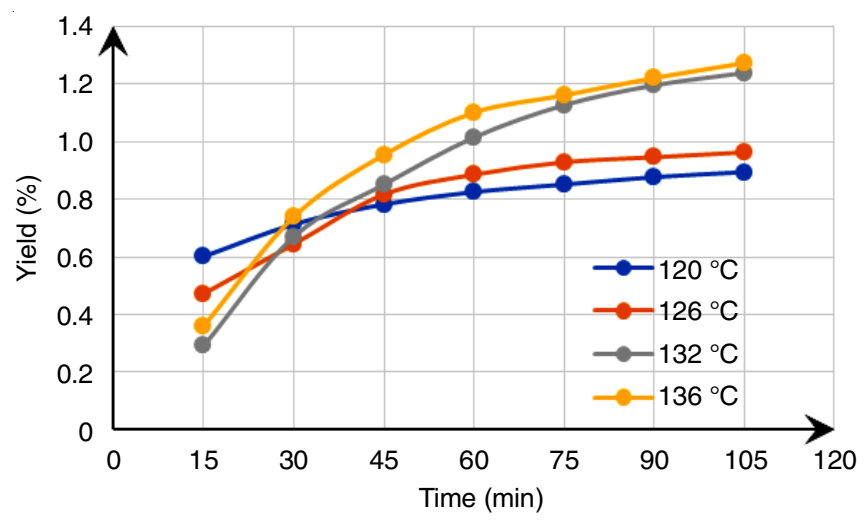

Fig. 2. Effect of distillation temperature on essential oil yield

Fig. 2 described the effect of temperature on yield of orange essential oil which peaked at $1.2728 \%$, corresponding to temperature of $136{ }^{\circ} \mathrm{C}$. Yields were $1.2384 \%$ at $132{ }^{\circ} \mathrm{C}$. However, the difference between the yield of extracted orange essential oil at 132 and $136{ }^{\circ} \mathrm{C}$ was not significant. We could found that increasing temperature leads to increase yield. However essential oil content in materials was certainly limited. Therefore, after a certain point, increasing temperature only leads to marginal improvement in oil yield. Because steam was used to separate the solid phase components, the high vapourization of water inside the mixture occurred more rapidly leading to permeation of water vapour and absorption of the essential oil in the tissues. The diffusion was therefore faster. Therefore, hydrodistillation at $132^{\circ} \mathrm{C}$ was the most optimal condition.

Effect of material size on yield: The orange peels were thick and hard and could affect the distillation process. To increase the efficiency of essential oil distillation, orange peels size must be reduced. After fixing time at $105 \mathrm{~min}$, the samples were distilled with different size (cut, grind and whole) at 132 ${ }^{\circ} \mathrm{C}$ and ratio of 1:2. Samples which used in the experiments were fresh samples that were not stored.

Fig. 3 showed the effect of sizes of raw materials on the yield of orange essential oil. It is seen that extraction of oil with ground materials had given the highest essential oil extraction efficiency, followed by cut and whole peel materials.

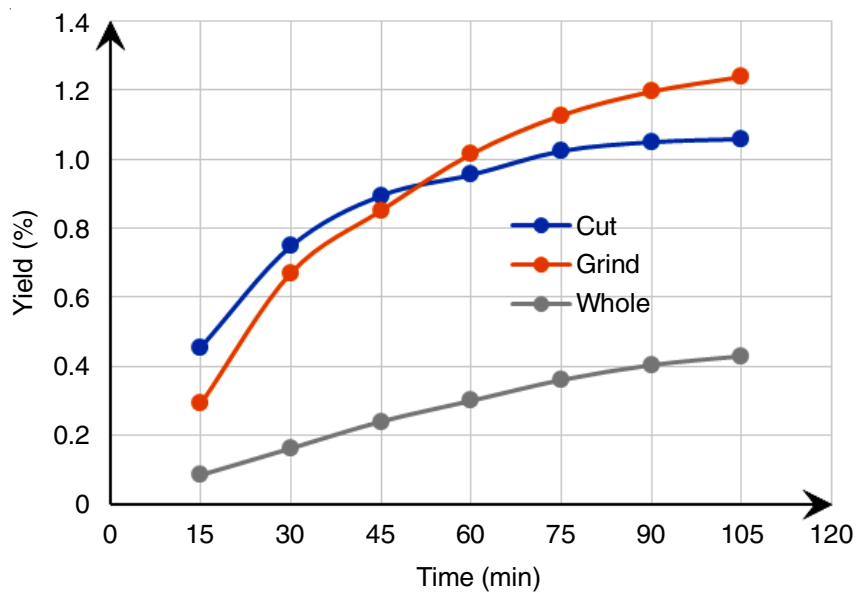

Fig. 3. Effect of size on orange peels essential oil yield 
The yields of orange essential oil were 1.2384, 1.0578, $0.43 \%$, respectively.

For ground materials, the cells that contain essential oils were broken, facilitating the penetration of into the tissues. The oil could be then released into the environment and the steam was responsible for attracting free essential oils.

Effect of storage time on yield: Experiments had been conducted on four samples in different storage time conditions (immediately used, 1 day, 3 days and 5 days) at $132{ }^{\circ} \mathrm{C}$, the ratio of solid/solvent $1: 2$, ground samples.

Fig. 4 showed the effect of storage time on yield of orange essential oil. The yield of essential oil had decreased from $1.2384 \%$ (immediately used) to $1.1352 \%$ (1 day storage) and reduced to $0.8944 \%$ ( 5 days storage) for orange peel materials. As a result, it is suggested that the material should be distilled immediately and the storage time should not be longer than 1 day storage. Because essential oils contain many volatile compounds, materials which were stored in long times can cause the diffusion of essential oil into the air by the effect from the surrounding environmental factors such as temperature and humidity.

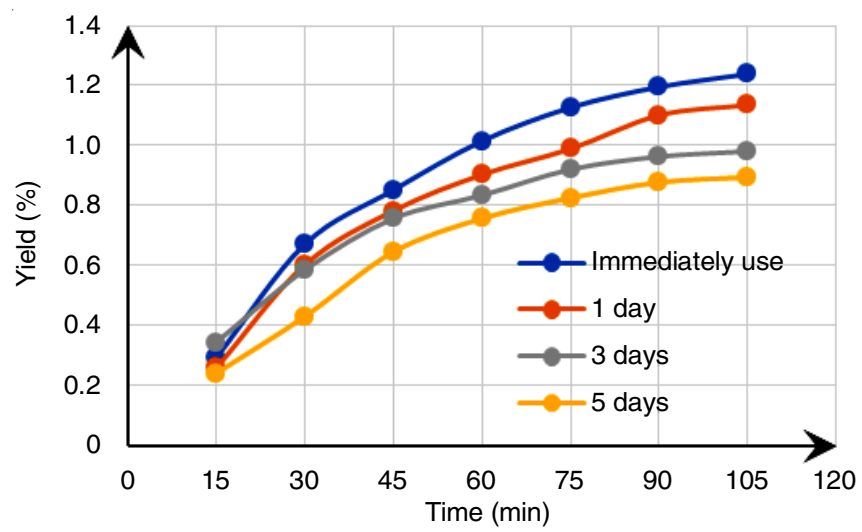

Fig. 4. Effect of storage time on orange peel essential oil yield

Effect of ratio solid/solvent on yield: After fixing the optimum distillation conditions $\left(105 \mathrm{~min}, 132^{\circ} \mathrm{C}\right)$, the effect of ratio of materials and solvents is investigated. The results of this experiment is showed in Fig. 5. In hydrodistillation, when heated the mixture of water and material, the water permeated the tissues which contain essential oils, broke down the essential oils and attracted the essential oil by steam. Based on the effect of ratio solid/solvent on the yield of essential oil (Fig. 5), the ratio of solid/water 1:2 with $20 \mathrm{~L}$ of water had given the best yield of $1.24 \%$ for orange essential oil. If the volume of water was low, the colloidal oil could not be dissolved. However, excess water could increase the diffusion of oil into the water. Water could therefore be easily absorbed into the material, improving efficiency of extraction. In addition, too much water led to dissolve or to emulsify the essential oils; reducing of the amount of oil and the economic efficiency of the distillation because it required more energy, time to heat and collect essential oils.

Kinetic modeling of hydrodistillation: The first order extraction constant $(\mathrm{k})$ and coefficient of determination $\left(\mathrm{R}^{2}\right)$ were calculated experimentally by referring to the linear plot (figures not shown), the results were in the range 0.0377-

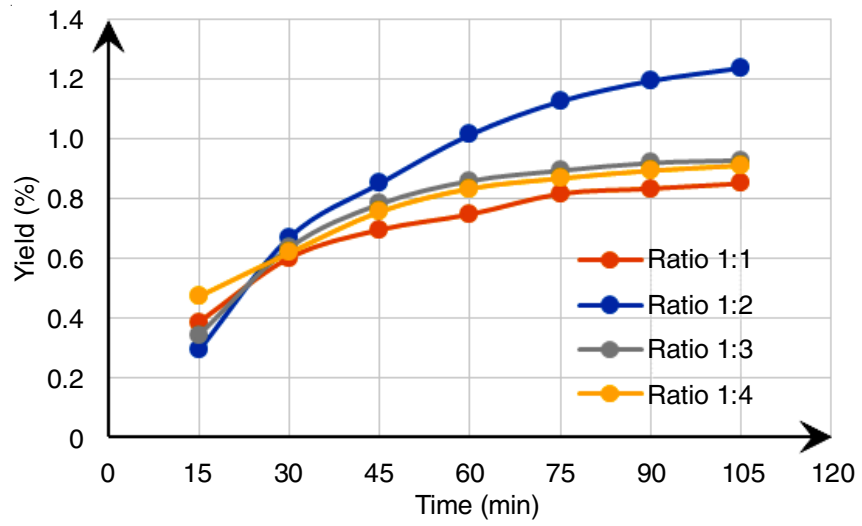

Fig. 5. Effect of ratio solid/solvent on orange peel essential oil yield

0.0452 and $0.9674-0.9976$. The straight line curve showed that correlative level between orange peel essential oil hydrodistillation process and first-order modeling was relatively high $\left(\mathrm{R}^{2}>0.95\right)$ when ground fresh materials were distillated at $132{ }^{\circ} \mathrm{C}$ at a different ratio. The essential oil removed per unit time is directly proportional to the essential oil remaining in the peel. Koul et al. [26] investigated steam distillation of lemon grass used firstorder kinetic model, the result showed that data of experiment perfectly followed the first order reaction kinetic [26].

Evaluation of essential oils: Sensory and physical properties of orange peels essential oil are shown in Table-2. It is showed that sensory and physical properties of pomelo and orange peels essential oil were their characteristic properties according to TCVN 11424:2016 standards, all of which showed that the essential oils obtained were good quality. The results of GC-MC analysis (Table-3) showed that D-Limonene component occurred the highest content for orange peels essential oil (97.279\%). Orange peels essential oil had met ISO and TCVN standards with acceptable quality.

\begin{tabular}{ll}
\multicolumn{2}{c}{ TABLE-2 } \\
& \multicolumn{1}{c}{$\begin{array}{c}\text { SENSORY AND PHYSICAL PROPERTIES } \\
\text { OF ORANGE PEELS ESSENTIAL OIL }\end{array}$} \\
\hline \multicolumn{1}{c}{ Properties } & \multicolumn{1}{c}{ Orange essential oil } \\
\hline Colour & Yellowish \\
Odour & Featured aroma of orange peels \\
State & Transparent liquid \\
Specific gravity $(\mathrm{g} / \mathrm{mL})$ & 0.843 \\
Refractive index & 1.472 \\
Optical rotation & $+97.16^{\circ}$ \\
\hline
\end{tabular}

\begin{tabular}{ccccc}
\multicolumn{5}{c}{ TABLE-3 } \\
\multicolumn{2}{c}{ GC-MS ANALYSIS OF ORANGE PEELS ESSENTIAL OIL } \\
\hline $\begin{array}{c}\text { Retention } \\
\text { time } \\
(\mathrm{min})\end{array}$ & $\begin{array}{c}\text { Substance } \\
\text { name }\end{array}$ & Content & Mass & $\begin{array}{c}\text { Interoperability } \\
\text { of mass } \\
\text { spectrometry }\end{array}$ \\
\hline 5.082 & $1 \mathrm{R}-\alpha$-Pinene & 0.741 & 136 & 937 \\
5.972 & $\beta$-Myrcene & 1.814 & 136 & 945 \\
6.811 & D-Limonene & 97.279 & 136 & 932 \\
10.468 & $\alpha-$-Terpineol & 0.166 & 154 & 911 \\
\hline
\end{tabular}

\section{Conclusion}

In this study, parameters involved in the hydrodistillation processing in pilot scale such as extraction time, temperature, solvent to solid ratio, material size, storage time that have been 
taken for obtaining optimial operating conditions. The orange peels essential oil, the maximum yield was $1.2384 \%$ (fresh matter) at distillation conditions (ground fresh material, the material-water ratio of 1:2, $105 \mathrm{~min}, 1326 \mathrm{C}$ ). There were some experiments which would be considered for scaling up. Yield and quality of essential oils were considered. Results from GC-MS analysis showed D-limonene was the most prevalent chemical constituent in orange essential oil, especially orange peel essential oil (>90\%). Hence, orange peel essential oil is a good source of $\mathrm{D}$-limonene. Plot of $\ln (1 / 1-\mathrm{u})$ versus $\mathrm{t}$ (where $\mathrm{u}$ is fractional oil uptake) showed that extraction of orange and pomelo essential oil by hydrodistillation follows first order kinetics.

\section{CONFLICT OF INTEREST}

The authors declare that there is no conflict of interests regarding the publication of this article.

\section{REFERENCES}

1. T.S. Vo, D.H. Ngo, L.G. Bach, D.N. Ngo and S.K. Kim, Process Biochem., 54, 188 (2017); https://doi.org/10.1016/j.procbio.2017.01.001.

2. N.P.T. Nhan, T.T. Hien, L.T.H. Nhan, P.N.Q. Anh, L.T. Huy, T.C.T. Nguyen, D.T. Nguyen and L.G. Bach, Diffus. Defect Data Solid State Data Pt. B Solid State Phenom., 279, 235 (2018); https://doi.org/10.4028/www.scientific.net/SSP.279.235.

3. A.N.Q. Phan, L.G. Bach, T.D. Nguyen and N.T.H. Le, J. Nanosci. Nanotechnol., 19, 974 (2019);

https://doi.org/10.1166/jnn.2019.15925.

4. T.T. Hien, N.P.T. Nhan, N.D. Trinh, V.T.T. Ho and L.G. Bach, Diffus. Defect Data Solid State Data Pt. B Solid State Phenom., 279, 217 (2018); https://doi.org/10.4028/www.scientific.net/SSP.279.217.

5. T. Tran, H. Nguyen, D. Nguyen, T. Nguyen, H. Tan, L. Nhan, D. Nguyen, L. Tran, S. Do and T. Nguyen, Processes, 6, 206 (2018); https://doi.org/10.3390/pr6110206.

6. P. Tongnuanchan and S. Benjakul, J. Food Sci., 79, R1231 (2014); https://doi.org/10.1111/1750-3841.12492.

7. D.R.L. Caccioni, M. Guizzardi, D.M. Biondi, A. Renda and G. Ruberto, Int. J. Food Microbiol., 43, 73 (1998); https://doi.org/10.1016/S0168-1605(98)00099-3.

8. M.C. González-Mas, J.L. Rambla, M.P. López-Gresa, M.A. Blázquez and A. Granell, Front. Plant Sci., 10, 12 (2019); https://doi.org/10.3389/fpls.2019.00012.

9. M.R. Moreira, A. Ponce, C.E. del Valle and S.I. Roura, LWT-Food Sci. Technol., 38, 565 (2005); https://doi.org/10.1016/j.lwt.2004.07.012.

10. Y. Sun and J.D. Oliver, Food Addit. Contam., 11, 549 (1994); https://doi.org/10.1080/02652039409374256.

11. M. Hyldgaard, T. Mygind and R.L. Meyer, Front. Microbiol., 3, 12 (2012); https://doi.org/10.3389/fmicb.2012.00012.

12. K. Fisher and C.A. Phillips, J. Appl. Microbiol., 101, 1232 (2006); https://doi.org/10.1111/j.1365-2672.2006.03035.x.
13. B. Uysal, F. Sozmen, O. Aktas, B.S. Oksal and E.O. Kose, Int. J. Food Sci. Technol., 46, 1455 (2011); https://doi.org/10.1111/j.1365-2621.2011.02640.x

14. A.E. Edris, Phytother. Res., 21, 308 (2007); https://doi.org/10.1002/ptr.2072.

15. T.M. Moraes, H. Kushima, F.C. Moleiro, R.C. Santos, L.R. Machado Rocha, M.O. Marques, W. Vilegas and C.A. Hiruma-Lima, Chem. Biol. Interact., 180, 499 (2009); https://doi.org/10.1016/j.cbi.2009.04.006.

16. A. Sarkic and I. Stappen, Cosmetics, 5, 11 (2018); https://doi.org/10.3390/cosmetics5010011.

17. P. Masango, J. Clean. Prod., 13, 833 (2005); https://doi.org/10.1016/j.jclepro.2004.02.039.

18. A. Yildirim, A. Cakir, A. Mavi, M. Yalcin, G. Fauler and Y. Taskesenligil, Flav. Fragr. J., 19, 367 (2004); https://doi.org/10.1002/ffj.1343.

19. R.M.F. Vargas, A.M. Lucas, M.S.T. Barroso, D.V. Dutra, M.V. Becker, C.A. Mondin and E. Cassel, J. Essen. Oil Bearing Plants, 15, 839 (2012); https://doi.org/10.1080/0972060X.2012.10644129.

20. O.O. Okoh, A.P. Sadimenko and A.J. Afolayan, Food Chem., 120, 308 (2010); https://doi.org/10.1016/j.foodchem.2009.09.084.

21. F. Perineau, L. Ganou and G. Vilarem, J. Chem. Technol. Biotechnol., 53, 165 (1992); https://doi.org/10.1002/jctb.280530210.

22. M.-T. Golmakani and K. Rezaei, Food Chem., 109, 925 (2008); https://doi.org/10.1016/j.foodchem.2007.12.084.

23. W. Guan, S. Li, R. Yan, S. Tang and C. Quan, Food Chem., 101, 1558 (2007); https://doi.org/10.1016/j.foodchem.2006.04.009.

24. M.A. Ferhat, B.Y. Meklati, J. Smadja and F. Chemat, J. Chromatogr. A, 1112, 121 (2006); https://doi.org/10.1016/j.chroma.2005.12.030.

25. Z.A.A. Aziz, A. Ahmad, S.H.M. Setapar, A. Karakucuk, M.M. Azim, D. Lokhat, M. Rafatullah, M. Ganash, M.A. Kamal and G.M. Ashraf, Curr. Drug Metab., 19, 1100 (2018); https://doi.org/10.2174/1389200219666180723144850.

26. V.K. Koul, B.M. Gandotra, S. Koul and S. Ghosh, Indian J. Chem. Technol., 11, 135 (2004).

27. H.B. Sowbhagya, S.R. Sampathu and N. Krishnamurthy, J. Food Eng., 80, 1255 (2007); https://doi.org/10.1016/j.jfoodeng.2006.09.019.

28. H.B. Sowbhagya, B.V. Sathyendra Rao and N. Krishnamurthy, J. Food Eng., 84, 595 (2008); https://doi.org/10.1016/j.jfoodeng.2007.07.001.

29. H.H. Muhammad, C.M. Hasfalina, J. Hishamuddin and Z.A. Zurina, Int. J. Chem. Eng. Appl., 3, 173 (2012); https://doi.org/10.7763/IJCEA.2012.V3.181.

30. S. Milojevic, D. Radosavljevic, V. Pavicevic, S. Pejanovic and V. Veljkovic, Hem. Ind., 67, 843 (2013); https://doi.org/10.2298/HEMIND121026009M.

31. M.N. Boukhatem, M.A. Ferhat, A. Kameli, F. Saidi and H.T. Kebir, Libyan J. Med., 9, 25431 (2014); https://doi.org/10.3402/ljm.v9.25431. 